\title{
Dealing with the Increasing Public Debt in Egypt
}

\author{
Ali A. Massoud ${ }^{1}$ \\ ${ }^{1}$ Associate professor at Economics Department, Faculty of Commerce, Sohag University, Egypt and a visiting scholar at \\ Claremont Institute for Economic Policy Studies, Claremont Graduate University, USA.
}

Correspondence: Ali A. Massoud, Sohag University, Egypt and Claremont Graduate University, USA

Received: August 18, 2014

Accepted: August 28, 2014

Available online: November 25, 2014

doi:10.11114/ijsss.v3i1.593

URL: http://dx.doi.org/10.11114/ijsss.v3i1.593

\begin{abstract}
The objective of this paper is to identify the magnitude of the public debt problem in Egypt and to provide some guidelines for policymakers in dealing with the increasing public debt. In the paper, the issue of public debt is looked at as a result of the interaction of fiscal policy and the economic performance, and not as a statistical concept only. It consists of four sections and an introduction. Section (1) provides an identification of the magnitude of the public debt problem in Egypt. Section (2) presents a forecast of the level of public debt in Egypt till the year 2020 using a VAR model. Section (3) provides a forecast for the size of the public debt in Egypt under various scenarios where both economic growth and fiscal policy were considered. Section (4) summarizes the findings and policy recommendations that came out of this study.

The conclusions drawn from this research may be summarized as follows. (1) Based on the model used in the paper and public debt indicators, public debt in Egypt is expected to be sustainable till the year 2020. (2) Economic growth has a very strong impact on reducing public debt in Egypt. (3) Fiscal consolidation is very important in reducing public debt because of its impact on economic growth. However, in the process of fiscal consolidation, the Egyptian government has to consider rationalizing spending and not to cut investment spending.
\end{abstract}

Keywords: Public Debt, Public Debt Sustainability, Fiscal Reaction Function, and Fiscal Consolidation.

\section{Introduction}

Increasing debt to GDP ratio is an important issue not only for developing and emerging market countries, but also for advanced economies as well. As a matter of fact, the debt to GDP ratio for advanced economies, as a group, is much higher than for developing and emerging countries, as another group. In 2010 the ratio of debt to GDP for the former group was $102 \%$ and it is expected to be $133 \%$ by the year 2020 . For emerging markets, the ratio of debt to GDP in 2010 was only $46 \%$ and it is expected to decline to $35 \%$ by the year 2020, Becker (2010).

What are the factors that cause debt to GDP ratio to increase? Abas, et al. (2013) argued that identifying the factors moving the debt to GDP ratio is not always straightforward. Even though the increases in this ratio are found to be associated with low or negative growth rate and weak primary balances, the underlying correlations vary across countries and time. They identified other factors that affect debt dynamics such as inflation, interest rates, and stock-flow adjustments. However, the impact of these factors is less clear than for primary balance and growth.

Regardless of what caused debt to increase in a country, keeping debt sustainable should be the main concern for policymakers because an infinite increase of debt hurts economic growth in the long run. High level of debt crowds out private investment and puts constraints on fiscal policy. Government debt is considered sustainable only if the government can serve its debt without taking measures that are economically and politically costly. Reinhart and Rogoff (2010 and 2012) argue that if the debt to GDP ratio exceeds 90\%, the economic growth will be affected negatively in a strong way. Baum, et al. (2013) supports the existence of debt threshold. They argue that in the Euro area, if the debt to GDP ratio exceeds 95\%, it will lead to a lower growth. Roubini (2001) challenged the existence of debt threshold as follows.

"As long as the debt ratio to GDP is stabilized over the medium term, it is considered as sustainable regardless of its level; i.e. a debt to GDP ratio of $150 \%$ is as sustainable as a debt to GDP ratio of 50\%"

Eberhardt and Presbitero (2013) also supported Robinin's view. Even though, they found some support for a nonlinear relationship between debt and long-run growth across countries, they found no evidence for common debt thresholds 
within countries over time. Pescatori, et al. (2014) also, found no evidence of any particular debt threshold above which medium-term growth prospects are dramatically compromised. However, they found that higher debt is associated with a higher degree of output volatility. Ghosh et al. (2010 and 2011) moved the argument forward and showed that even what is used to be considered formerly as a sustainable level of debt may become unsustainable and triggers default. Many other studies have tried to test the sustainability of public debt in various countries and across nations \& regions, i.e.,Sopek (2011), Di Bella (2008), Tanner and Samake (2006), Mediros (2012), Stoian (2011). The IMF and the World Bank also have been given an increasing attention to debt sustainability. The IMF conventional framework on "sustainability assessment" was first released in 2002. In 2005, the World Bank and the IMF together created the Debt Sustainability Analysis (DSA) in order to guide the low-income countries borrowing decisions and to reduce the chances of excessive debt accumulations. In 2014, IMF released its new toolkit for assessing public debt sustainability in countries that have access to international capital markets. This approach is called public debt sustainability analysis in market access countries (MAC DSA). It takes a more holistic view, assessing the level and trajectory of debt, government financing needs, and vulnerability in the debt structure. For more details on this issue, review IMF (2013), World Bank and the IMF (2012, 2009 and 2001), Escolano (2010), and Akyiiz (2007).

It might be argued that debt limits are not static over time. Rather, they change from time to time and across countries as well. The main factors affecting the debt limit for a country may be identified as follows. (1) The performance of the national economy and its ability to recover after shocks. (2) The willingness and the ability of the authorities to undertake serious fiscal adjustments. Abiad and Ostry (2005) emphasized countries surplus-generating capacity that are linked to its fundamentals, the country historical experience in managing its debt \& its budget and the country's fiscal institutions to deliver primary surpluses as main factors that affect debt limit.

In managing public debt, we should consider the activities that debt finances. Public debt that finances growth enhancing activities, i.e., infrastructure, is expected to increase the surplus-generating capacity. However, public debt that finances current expenditure for the government is more likely to put constraints on fiscal policy over the medium and long term. For many of low-income countries in order to meet their public investment needs in infrastructure, energy, health, education, and other critical sectors, they have to depend on debt in financing these investments. Building up public debt can have destructive outcomes on growth over the long run via what is known as a debt overhang. Moreover, countries cannot carry out an increasing debt over the long term. This leads to debt unsustainability problems.

In the process of debt management, we should differentiate between solvency and liquidity. The former concept is related to a medium to long-term and requires that the government's net present value budget constraint to hold. This means that the net present value of the government's future primary balances must be at least equal to the net present value of the government debt. While the concept of liquidity is related to a short-term time frame, it requires that the government is able to serve its debt obligations in the short term. The differentiation between external and internal debt is another issue that we have to consider in debt management process. Buffie, et al. (2012) argues that while external borrowing provides external resources, it has two main shortages. (1) It may be attached to undesirable conditions. (2) In the presence of weak structural and policy conditions and / or unexpected exogenous shocks, it induces unsustainable public debt dynamics. Even though domestic borrowings are favorable for policymakers because they give them a broad range of options to deal with public debt, they worsen the crowding out of the private investment. Also, they may lead to excessive borrowing by the government.

Chan-Lau and Santos (2010) identified six principles, advanced by the IMF and the World Bank, for sound management of the risks associated with debt. These principles are: (1) the alignment of the objectives of debt management, monetary policy, and fiscal policy; (2) adequate transparency and accountability; (3) institutional capacity; (4) the optimal debt structure; (5) an appropriate risk-management framework; and (6) developing an efficient government security market.

Debt reduction is one of the tools that government uses in managing public debt. Great Britain, France, and Germany succeeded to reduce their debt dramatically in the past. Even developing and underdeveloped countries managed to do so by a high level of policy commitment to reduce their debt. This is what international experiences also emphasize, i.e. , Guyana managed to decrease the percentage of public debt to GDP form 575\% in 2002 to $183 \%$ in 2005 as a result of debt reliefs, structural reform that enhances growth, i.e. modernization of sugar sector, and fiscal consolidation. Apergis and Cooray (2013) has shown that the only aggressive growth policy could permit a country, such as Greece to achieve debt sustainability. The debt problem started in Greece as the debt ratio to the GDP reached a high level of $171 \%$ of GDP in 2011. This raised a question regarding Greece's ability to pay its debt back. In order to calm down the market, the Greek government adopted very tough fiscal measures including cutting expenditures and raising taxes. These measures hurt growth and put the country on a vicious cycle and deep recession. Most of the literature on debt reduction encourages public spending cuts in order to restore the primary balance. However, reducing public spending may harm 
economic growth over the medium term, which in return harms the fiscal position for the country. Baldacci et al. (2013) has shown that public debt consolidations should be gradual and based on an appropriate combination of revenues' increase and public spending cuts. They also emphasized that the public spending cuts should not include the public investments that enhance growth over the medium and long terms. Reinhard and Rogoff (2013) cited five ways to reduce large debt to GDP ratios that authorities had used one or a combination of them. (1) Economic growth. (2) Fiscal adjustment-austerity. (3) Explicit (de jure) default or restructuring. (4) Inflation. (5) A steady dose of financial repression accompanied by a steady dose of inflation.

Public debt and its sustainability has been a major concern for policymakers in Egypt. Before the adoption of Economic Reform Program in Egypt in the 1990s, external debt was the main issue. Holding a high level of external debt, given the current account deficit and the continuous depreciation of the Egyptian Pound, may lead not only to a liquidity problem but also it could lead to an insolvency problem. Policymakers in Egypt have got this correctly and moved steadily toward financing the deficit in public budget via domestic debt. Domestic debt has increased dramatically during the last two decades making policymakers in Egypt facing a great challenge. This challenge is how can Egypt continue to serve its debt without adopting unrealistically large correction to its public budget? In other words, how can Egypt achieve both liquidity and solvency? It might be argued that the real challenge for the Egyptian policymakers is not the external debt; rather it is the domestic debt. From the liquidity aspect, Egypt must be able to find sufficient amount of financing in each period to close any financing gaps without having to resort disorderly adjustment. From a solvency perspective, Egypt must be able to generate sufficient funds in the coming periods to cover its debt service obligations without indefinitely accumulating debt. If policymakers in Egypt are able to do that, the public debt in Egypt will be sustainable in the future.

There are two studies that dealt with public debt sustainability in Egypt. The first study was El-Mahdy and Torayeh (2009). They examined two issues related to debt in Egypt. (1) They examined the impact of domestic debt on economic growth in Egypt during the period from 1981 to 2006. By using a co-integration model, they found out that domestic debt had a robust and negative impact on economic growth. (2) They also examined the sustainability of domestic debt. They found out that domestic debt in Egypt during this period has been sustainable. The second study was Abutaleb and Hamad (2010). They assessed the foreign debt policy in Egypt during the period from 1985 to 2008 and contrasted it with the optimal policy. They used a stochastic control approach in order to determine the optimal debt policy. They found out that Egypt's foreign debt was higher than the optimal level before 1997. However, after 1997, the foreign debt was below its optimal level.

The objective of this paper is to identify the magnitude of the public debt problem in Egypt and to provide some guidelines for policymakers in dealing with the increasing public debt. In this paper, the public debt is looked at as a result of the interaction of fiscal policy and the economic performance, and not as a statistical concept only. This differs from the previous studies based only on what is known in literature as the present- value borrowing constraints according to which government must intertemporally balance their budgets by setting the current value of debt equal to discounted sum of expected future surpluses. The violation of this constraint leads to a debt explosion over time at rates faster than the economic growth rates in this country.

The second part of the paper is organized as follows. Section (1) provides an identification of the magnitude of the public debt problem in Egypt. Section (2) presents a forecast of the level of public debt in Egypt till the year 2020. Section (3) provides a forecast of the size of the public debt in Egypt under various scenarios. Section (4) summarizes the conclusion and policy recommendations that come out of this study.

\subsection{The Magnitude of the Public Debt in Egypt}

Over the past two decades, public debt in Egypt has increased dramatically. In 1991, net domestic debt was only 71.4 billion L.E. It increased steadily to reach a level of more than 1.6 trillion L.E. by the end of December 2013 which accounts for 80.6 \% of GDP. Figure (1) shows the size of public debt in Egypt from 1991 to 2013. 


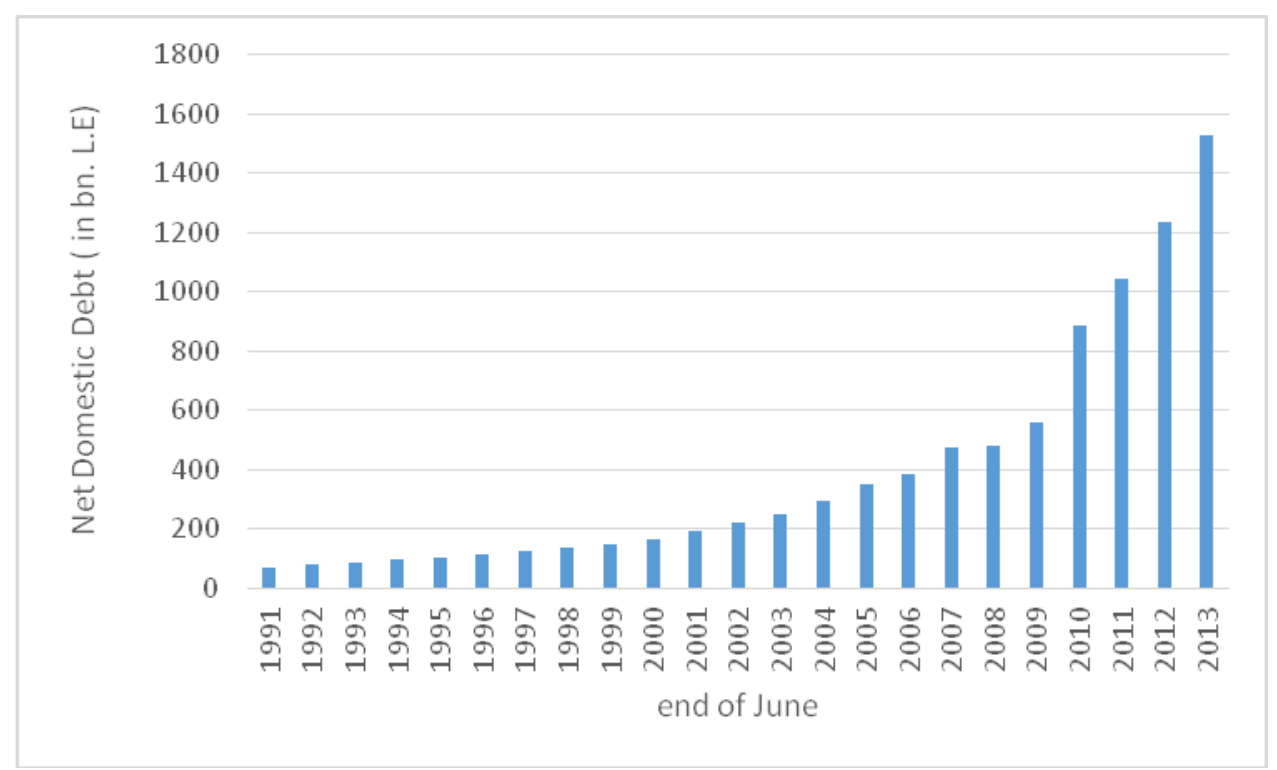

Figure 1. Net domestic debt in Egypt from 1991 to 2013

The source of data: The Central Bank of Egypt, various issues of annual report.

Egypt does not only depend on domestic debt in financing its budget. It also depends on external debt. Over the past two decades, the total external debt in Egypt has been fluctuating. In 1993, the total external debt was 30.3 billion \$. It increased to reach a level of more than 47 billion $\$$ by the end of December 2013. It accounted for $15.8 \%$ of GDP and its service accounted for $11 \%$ of total exports of goods and services. The share of short term debt was $8.5 \%$ of the total external debt and $21.4 \%$ of the net international reserves. The ratio of external debt to export of goods and services was $474.7 \%$ which is very high. Government was the main holder of external debt in Egypt. The government external debt represents $62.5 \%$ of the total external debt.

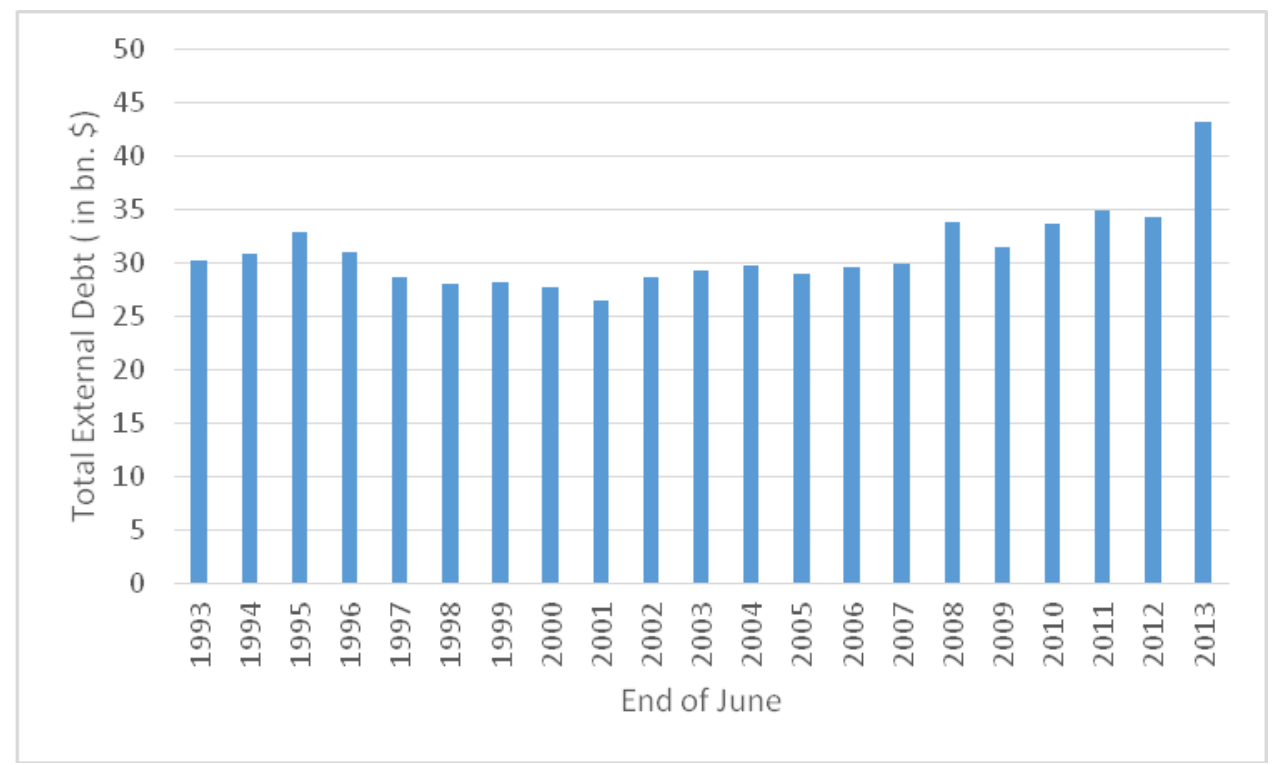

Figure 2. Total external debt in Egypt from 1993 to 2013

The source of data: The Central Bank of Egypt, various issues of annual report.

Figure (3) shows that the Egyptian government has changed its policy regarding the structure of debt. In 1993, while domestic debt as percentage of GDP was $61 \%$, the percentage of external debt to GDP was $64.5 \%$. After that, external debt as a percentage of GDP has declined sharply. It was only 13.2\% of GDP by the end of 2012. While domestic debt 
as a percentage of GDP stayed high at a level of $75.1 \%$ of GDP at the same period, this means that the Egyptian authorities depend more on domestic debt and reduce its dependency on external debt as a source of financing its budget deficit.

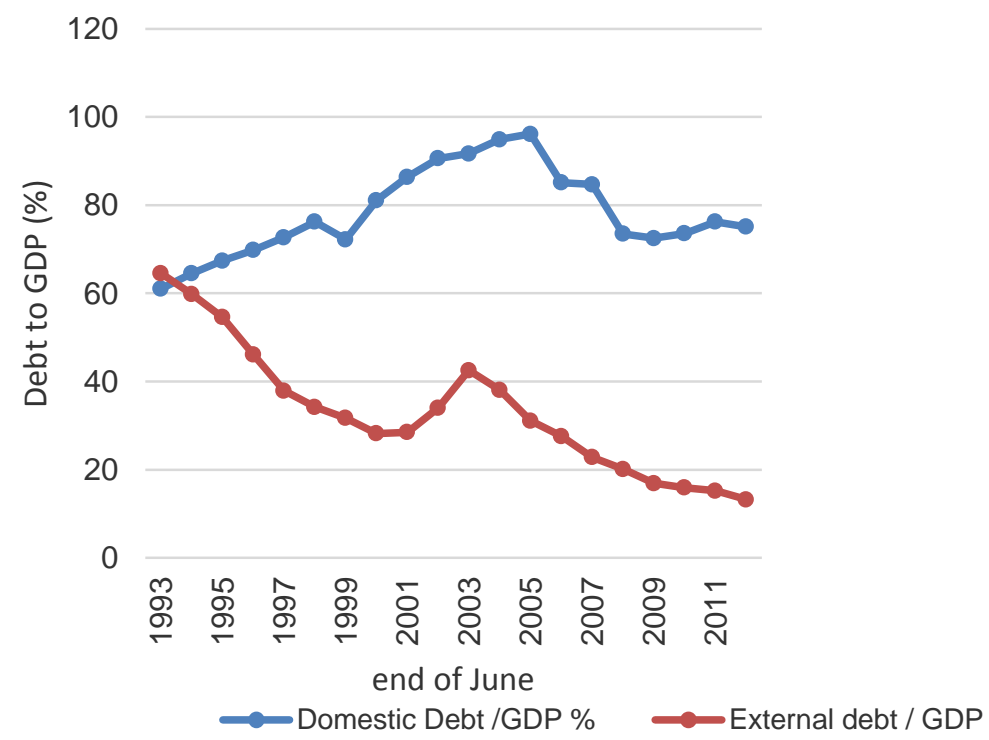

Figure 3. Domestic vs. External Debt in Egypt from 1993 to 2013

The source of data: The Central Bank of Egypt, various issues of annual report.

The question is: why should we have concern about the rising level of public debt in Egypt? The answer is that Egypt pays $26.5 \%$ of its public budget in forms of domestic and foreign interest. This is very close to the share of the employees' compensations which account for $30.6 \%$ of the total expenditure. It is very obvious that public debt in Egypt puts heavy constraints on its fiscal policy. Also there are three other reasons for the Egyptian authorities to be concerned about the increasing public debt in Egypt. (1) A country with high public debt ratio faces increasing difficulties in accessing financial market in the short term and it could suffer from a serious debt sustainability problem over the medium term. (2) It may lead to a default or inflationary finance. The default most likely leads to a financial crisis. For inflation even though it reduces the real cost of debt service; it is associated with higher interest rate which is also expected to increase debt service, Apergis and Cooray (2013). (3) High public debt ratios may crowed out private investments. (4) External debt could lead to a financial crisis similar to what happened in Latin America in the 1980s.

\section{Forecasting the Magnitude of the Public Debt in Egypt}

In order to forecast the magnitude of the public debt in Egypt over the coming period, I used a Vector Autoregression (VAR) model. Five variables were included in this model as follows: Domestic Debt / GDP (\%), Real GDP per Capita Growth Rate, Overall Public Budget Deficit / GDP (\%), Inflation, and Real Interest Rate. The variables were used in the model in the same order as stated above. The World Development Indicators (WDI) published by the World Bank, were the source of the data for the real GDP per capita growth rate, inflation, and real interest rate. While the Central Bank of Egypt (CBE) was the source of data used for domestic debt and public deficit (primary balance). The data used in the model covers the period from 1991 to 2012. Data was transferred from annual frequency to quarterly using E-Views 8.

Because stationarity is an important issue in time series data as well as in VAR models, I conducted Dickey-Fuller tests for unit root to all variables. Augmented Dickey-Fuller tests for unit root suggest that all variables have unit roots. In order to make the series stationary, I took the long and the first difference for all series. By conducting Augmented Dickey-Fuller tests for the new series, all variables were found to be stationary at I(1). Following Medeiros (2012), the optimal number of lags for this model is two lags.

To forecast the magnitude of public debt in Egypt using the model explained above, first I estimated the model, and then I forecasted the future values of public debt to GDP (\%) in the baseline scenario. Figure (4) shows the actual size of public debt as a percentage of GDP through the period from the first quarter of year 1991 to the fourth quarter of year 2012. This figure also shows the forecasted size of public debt as a percentage of GDP from the first quarter of year 2013 to the fourth quarter of year 2020. According to it, the public debt to GDP ratio is forecasted to be $85.5 \%$ at the end of year 2020 compared with the current percentage which is $77.7 \%$. This assumes that the Egyptian government 
will not adopt any radical changes in its fiscal \& monetary policy and economic growth will grow at the same level as it used to from 1991 to 2012. On one hand, if the Egyptian government adopts more radical fiscal policies that reduce budget deficit and enhance economic growth over the medium term, I expect that the size of public debt as a percentage of GDP will decrease substantially. However, on the other hand, if the political and social instability that have been taking place in Egypt after $25^{\text {th }}$ of January 2011 continues over the medium term; the Egyptian authorities are not able to adopt an appropriate fiscal policy; the economic growth stays in its low levels, the public debt as a percentage of GDP is expected to be even worse than this forecasted value.

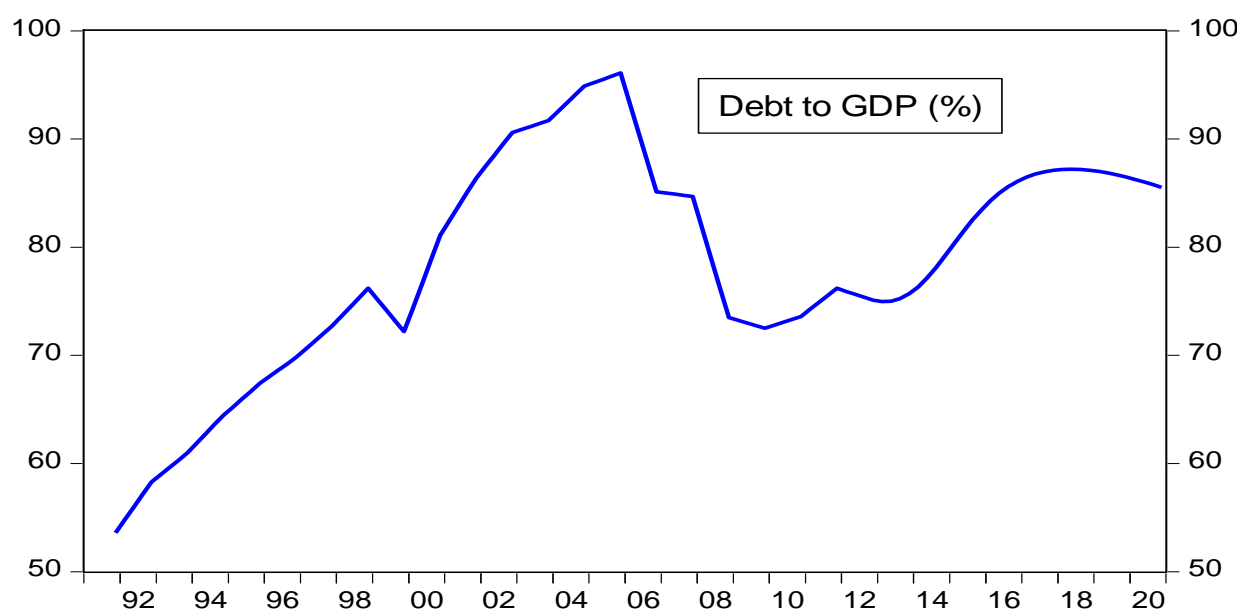

Figure 4. The Actual and Forecasted Debt to GDP (\%) in Egypt from 1991 to 2020

Table (1) shows in more details the magnitude of public debt in Egypt as forecasted in this model.

Table 1. The Forecasted Debt to GDP (\%) in Egypt from 2014 to 2020

\begin{tabular}{lccccccc}
\hline End of Year & $\mathbf{2 0 1 4}$ & $\mathbf{2 0 1 5}$ & $\mathbf{2 0 1 6}$ & $\mathbf{2 0 1 7}$ & $\mathbf{2 0 1 8}$ & $\mathbf{2 0 1 9}$ & $\mathbf{2 0 2 0}$ \\
\hline Debt / GDP $(\boldsymbol{\%})$ & 79.2 & 83.4 & 86.1 & 87.1 & 87.1 & 86.5 & 85.5 \\
\hline
\end{tabular}

To test the accuracy of the model forecasts, six quarters of available actual data on the ratios of debt to GDP were compared with the forecasted values of the ratios by the model over the same period. Figure (5) provides a comparison between the actual and the forecasted magnitude of public debt as a percentage of GDP. Through the period from the first quarter of year 2013 to the second quarter of year 2014, as figure (5) shows, the model provides a reasonably acceptable forecast of the magnitude of public debt in Egypt. Over the six quarters that forecasted and actual magnitude of public debt in Egypt were compared, the average difference between the actual and forecasted values was only $0.6 \%$ with the maximum difference of $2 \%$, a minimum difference of $0.1 \%$ and a standard deviation of $1.3 \%$.

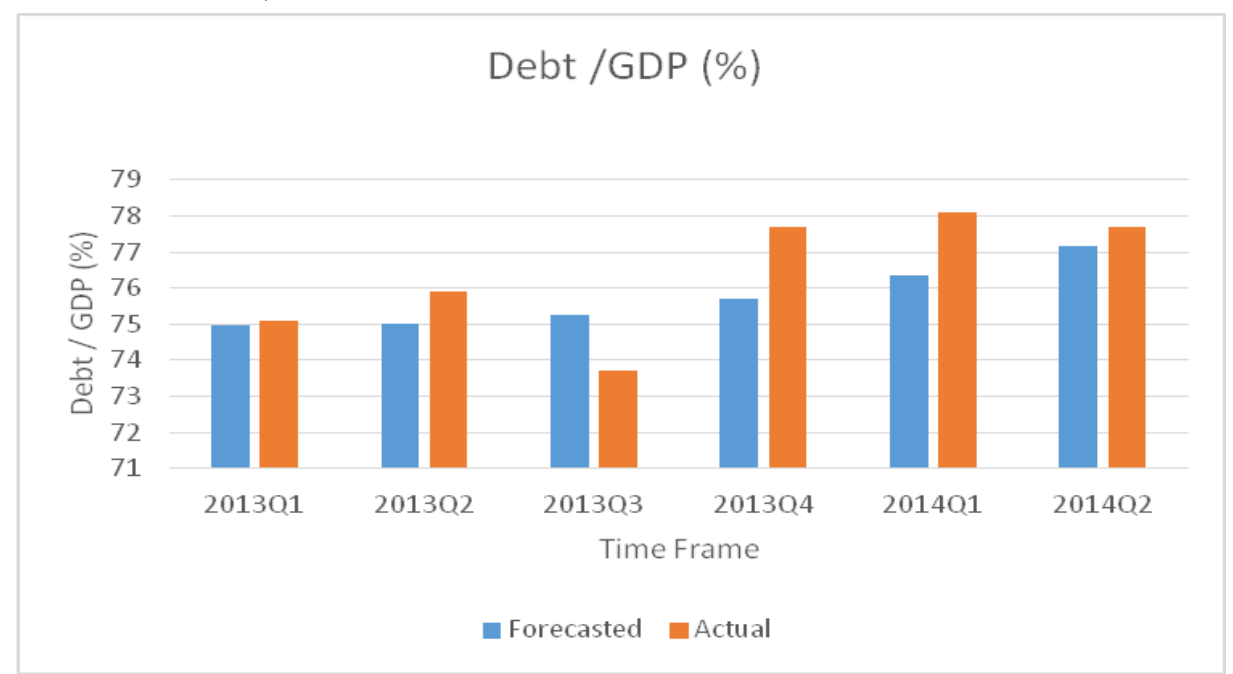

Figure 5. Forecasted vs. Actual Debt to GDP (\%) in Egypt from 2013q1 to 2014q2 


\section{Forecasting the Magnitude of the Public Debt in Egypt under Various Scenarios}

This section discusses six scenarios for the Egyptian authorities to tackle public debt. Tables (2 and 3) explain these scenarios and the outcome of each of them on the magnitude of public debt. The baseline scenario assumes that the Egyptian authorities do not change its past policies. Scenario (1) and scenario (2) suggest that the Egyptian authorities set and achieve a target of the budget deficit at 2 standard deviation and 3 standard deviation above its historical mean, respectively. Scenarios (1) and (2) also indicate that the Egyptian economy will grow at its historical rates. Scenarios (3) to (6) assume that the Egyptian authorities set and achieve a target of a budget deficit at 3 standard deviation above its mean. In these four scenarios, the Egyptian economy is expected to grow at a level that diverges from its historical rates. In scenarios (3) and (4), it is argued that the Egyptian economy will grow at 3 and 2 standard deviation above its historical mean, respectively. While in Scenarios (5) and (6), I assume that the Egyptian economy will grow at 1 and 2 standard deviation below its historical mean. In summary, scenarios from (3) to (6) take into account the performance of the Egyptian economy beside the commitment of the Egyptian fiscal policy.

Table 2. Description of various scenarios for the Egyptian authorities

\begin{tabular}{|c|c|}
\hline Scenario & Description \\
\hline Baseline Scenario & Based on the historical trend and there are no targets set by the government \\
\hline Scenario (1) & Budget deficit to GDP (\%)is set at $12.74 \%, 2$ s.d. above its historical mean \\
\hline Scenario (2) & Budget deficit to GDP (\%)is set at $16.04 \%, 3$ s.d. above its historical mean \\
\hline \multirow[t]{2}{*}{ Scenario (3) } & Budget deficit to GDP (\%)is set at $16.04 \%, 3$ s.d. above its historical mean \\
\hline & Economic growth $(\%)$ is $6.07 \%, 3$ s.d. above its historical mean \\
\hline \multirow[t]{2}{*}{ Scenario (4) } & Budget deficit to GDP (\%)is set at $16.04 \%, 3$ s.d. above its historical mean \\
\hline & Economic growth $(\%)$ is $5.63 \%, 2$ s.d. above its historical mean \\
\hline \multirow[t]{2}{*}{ Scenario (5) } & Budget deficit to GDP (\%)is set at $16.04 \%, 3$ s.d. above its historical mean \\
\hline & Economic growth $(\%)$ is $1.31 \%, 1$ s.d. below its historical mean \\
\hline \multirow[t]{2}{*}{ Scenario (6) } & Budget deficit to GDP (\%)is set at $16.04 \%, 3$ s.d. above its historical mean \\
\hline & Economic growth $(\%)$ is $-0.13 \%, 2$ s.d. below its historical mean \\
\hline
\end{tabular}

Note: s.d. denotes the standard deviation.

As table (3) shows, if the Egyptian authorities continue in the future implementing the same policies they have been using in the past, the level of public debt as a percentage of GDP is expected to reach $85.5 \%$ by the year 2020 compared with the current level which is $75.1 \%$. However, if the Egyptian authorities decrease the budget deficit as a percentage of GDP form $14.1 \%$ ( the current level) to $12.74 \%$, as was set in scenario (1), the debt level in the year 2020 is expected to be $84.7 \%$ which is less than the level of public debt in the baseline scenario. Scenario (2) shows that if the Egyptian authorities increase the budget deficit and the economy grows at the same rates it has been growing in the past, the debt level is expected to be worse even more and reach to $87.7 \%$. Scenarios (4) to (6) show to what extent economic growth makes difference in affecting the public debt level in Egypt even though with high levels of budget deficit. If the Egyptian economy grows in rates higher than it was in the past, as set in scenarios (3) and (4), the public debt will decrease in the future compared to its level in scenario (2). Scenarios (5) and (6) show to what extent the weak performance of the Egyptian economy will have negative impacts on the level of the public debt in Egypt. Figure (6) provides a comparison between these six scenarios regarding their impact on public debt in Egypt. According to the analysis of all these scenarios, we may conclude:

1- Public debt in Egypt is going to be sustainable. In other words, it is not going to get out of control over the period till the year 2020.

2- Achieving high rates of economic growth is very important for reducing the ratio of debt to GDP in the future.

3- Even though reducing budget deficit has less impact on debt reduction than achieving high rates of economic growth; it is very important in order to make fiscal policy more effective in enhancing the stability and growth.

Figures (1) to (3) in appendix (1) provide a comparison among different scenarios. Also, more details for the six scenarios at quarter frequency are provided in figures (4) to (9) in appendix (1). 
Table 3. Debt to GDP (\%) for the six scenarios

\begin{tabular}{cccccccc}
\hline & Debt & Debt & Debt & Debt & Debt & Debt & Debt \\
& /GDP \% & /GDP \% & /GDP \% & /GDP \% & /GDP \% & /GDP \% & /GDP \% \\
Year & SCB & SC1 & SC2 & SC3 & SC4 & SC5 & SC6 \\
\hline $\mathbf{2 0 1 0} *$ & 73.6 & 73.6 & 73.6 & 73.6 & 73.6 & 73.6 & 73.6 \\
$\mathbf{2 0 1 1} *$ & 76.2 & 76.2 & 76.2 & 76.2 & 76.2 & 76.2 & 76.2 \\
$\mathbf{2 0 1 2} *$ & 75.1 & 75.1 & 75.1 & 75.1 & 75.1 & 75.1 & 75.1 \\
$\mathbf{2 0 1 3} * *$ & 75.7 & 74.2 & 76.3 & 76.2 & 76.2 & 76.4 & 76.5 \\
$\mathbf{2 0 1 4} * *$ & 79.2 & 75.5 & 79.0 & 78.6 & 78.6 & 79.1 & 79.2 \\
$\mathbf{2 0 1 5} * *$ & 83.4 & 78.5 & 81.9 & 81.3 & 81.4 & 82.1 & 82.3 \\
$\mathbf{2 0 1 6} * *$ & 86.1 & 80.9 & 84.3 & 83.5 & 83.6 & 84.6 & 84.9 \\
$\mathbf{2 0 1 7} * *$ & 87.1 & 82.4 & 85.8 & 84.9 & 85.0 & 86.2 & 86.5 \\
$\mathbf{2 0 1 8} * *$ & 87.1 & 83.5 & 86.9 & 85.6 & 85.8 & 87.0 & 87.4 \\
$\mathbf{2 0 1 9} * *$ & 86.5 & 84.3 & 87.5 & 85.9 & 86.1 & 87.4 & 87.8 \\
$\mathbf{2 0 2 0} * *$ & 85.5 & 84.6 & 87.7 & 85.8 & 85.9 & 87.3 & 87.7 \\
\hline & & & $* *$ Forecasted & & &
\end{tabular}

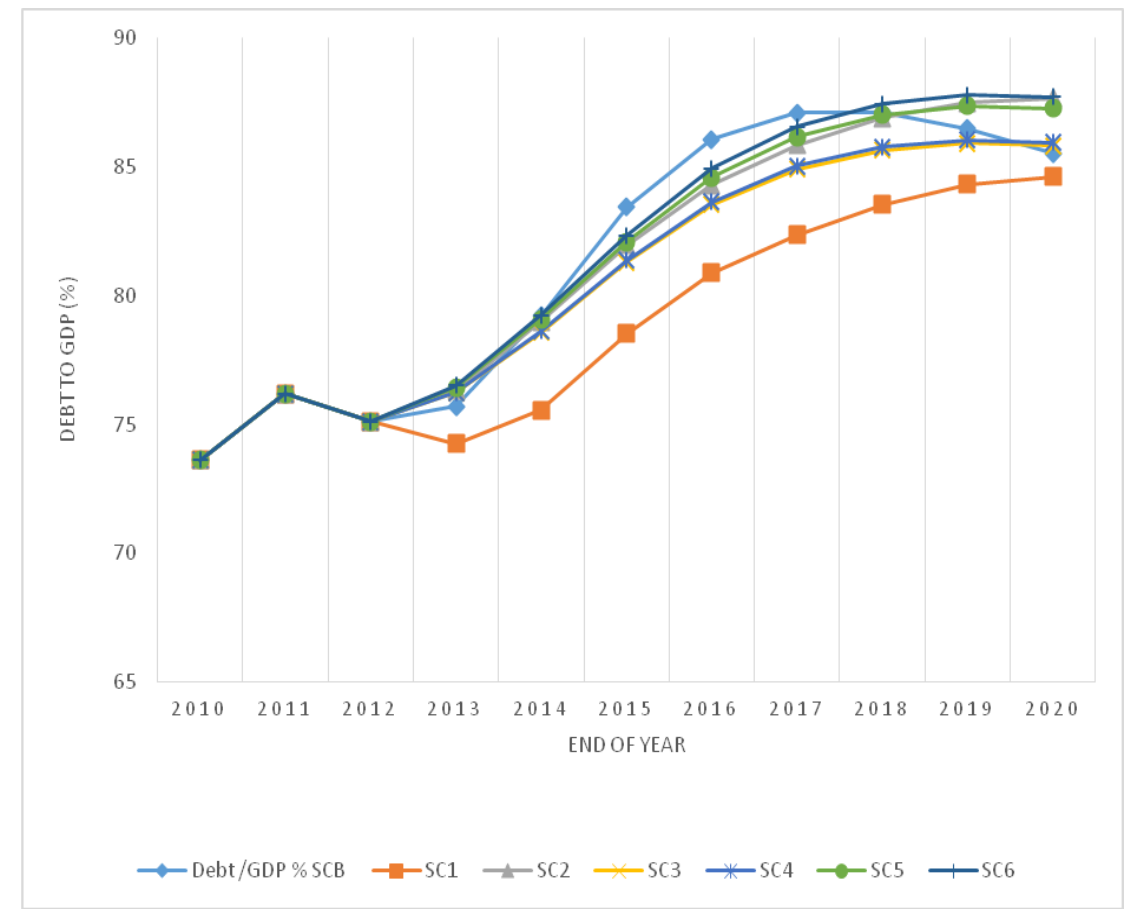

Figure 6. Debt to GDP (\%) for the six scenarios

\section{Conclusions and Policy Recommendations}

The analysis of the scenarios discussed in this paper produces important findings. First, though the public debt in Egypt is sustainable, Egyptian authorities should pay a great attention to the increasing accumulation of public debt. Any unnecessary accumulation of public debt must be avoided in order not to weaken the fiscal policy farther. Second, in order to keep this level of debt under control, the Egyptian government must adopt policies that enhance economic growth and it has to undertake fiscal adjustment. Third, to deal with debt sustainability correctly in Egypt, we have to 
make a distinction between domestic debt and external debt. Domestic debt issued in Egyptian Pound offers a far wider range of partial default options than does foreign currency-dominated external debt, Reinhart and Rogoff (2013). The implications of that approach can be summarized in two points: (1) The Egyptian government can stuff debt into local pension funds, state-owned banks, and public insurance companies. This can be done through forcing these institutions to accept lower rates of return on their investments in public loans \& bonds than they might otherwise accept. (2)The Egyptian government can reduce domestic debt through inflation if it faces problem in repaying public debt back. These options, even they are very difficult and they have strong and negative consequences on financial stability and economic growth, are not available for the government in the case of external debt.

Based on this study, the following is a summary of most relevant recommendations directed to the Egyptian authorities in order to deal with the problem of public debt.

1- The Egyptian government must rationalize public expenditures, i.e., move toward monetary subsidies instead of commodity subsidies; consider the left of energy subsidies seriously and endeavor to change its magnitude $\&$ structure. The expenditure should move more toward capital expenditure. However, the Egyptian government must take into consideration the negative impact of lowering government spending and higher taxes on economic growth, which could hurts the debt to GDP ratio in the short run in the process of fiscal consolidation.

2- Egyptian government should adopt economic policies that enhance investment and economic growth. High level of productive investment and economic growth typically generates additional tax revenue without necessitating an increase in tax rates.

3- In order to make debt sustainable in the future, Egyptian government has to strengthen the institutional capacity of generating revenue.

4- Fiscal decentralization is an important aspect that Egyptian government has to take in consideration. Fiscal decentralization leads to a better use of public spending and enhances growth at the governorate level.

5- The coordination between fiscal policy and monetary policy is a very important issue in order to maintain the domestic real interest rate below the real output growth rate and to ensure a stable inflation and exchange rate. For instance, low interest rate has two effects: first, it improves the budget balance as the government issues new bonds to finance the remaining deficit and the old debt. Second, low interest rate encourage investors to invest more and consumers to spend more, an action which may lead to an increase in GDP and a decline in debt to GDP ratio, Abas (2013). Stable inflation and exchange rate reduce the risk premium in Egypt. This encourages foreign investors and strengths the access to the international financial markets.

6- The Egyptian government may consider financial repression as a tool to be used over the short term in order to reduce the burden of the domestic debt. It can do so by forcing the state banks and insurance companies to lend the government at a rate less than it would lend otherwise.

7- Egyptian authorities need to engage in debt relief arrangements and consider the option of debt relief and development swaps. Debt relief takes financial obligations off the government's shoulder which increases the fiscal space for the government.

\section{References}

Abbas, A., Akitoby, B., Andritzky, J., Berger, H., Komastsuzaki, T., \& Tyson, J. (2013). Dealing with High Debt in an Era of Low Growth. IMF Staff Discussion Note, SDN/13/07.

Abiad, A. \& Ostry, J. D. (2005). Primary Surpluses and Sustainable Debt Levels in Emerging Market Countries. IMF Policy Discussion Paper, PDP/05/6.

Abutaleb, A., \& Hamad, M. (2010). Optimal foreign Debt for Egypt: A Stochastic Control Approach. The Inauguration Conference for Launching Information and Decision Support Center-Working Paper Series (IDSC-WPS), held on Sunday 28 March 2010, In Cairo, Egypt.

Akyiiz, Y. (2007). Debt Sustainability in Emerging Markets: A Critical Appraisal. DESA Working Paper, 61.

Apergis, N., \& Cooray, A. (2013). New Evidence on the Remedies of the Greek Sovereign Debt Problem. HELLENIC OBSERVATORY European Institute, GreeSE Paper, 79.

Baldacci, E., Gupta, S., \& Mulas-Granados, C. (2013). Debt Reduction, Fiscal Adjustment, and Growth in Credit-Constrained Economics. IMF Working Papers, WP/13/238. http://dx.doi.org/10.5089/9781475516500.001

Baum, A., Checheritan, C., \& Rother, P. (2013). Debt and Growth: New Evidence from the Euro Area. Journal of International Money and Finance, 32, 809-21. http://dx.doi.org/10.1016/j.jimonfin.2012.07.004 
Becker, S. (2010). Public debt in 2020, A sustainability analysis for DM and EM economies. Deutsche Bank Research, Current Issues.

Buffie, E., Berg, A., Pattillo, C., Portillo, R., \& Zanna, L. (2012). Public Investments, Growth, and Debt Sustainability: Putting Together the Pieces. IMF Working Paper, WP/12/144.

Chan-Lau, J. A., \& Santos, A. O. (2010). Public Debt Sustainability and Management in a Compound Option Framework. IMF working paper, WP/10/2. http://dx.doi.org/10.5089/9781451961676.001

Di Bella, G. (2008). A Stochastic Framework for Public Debt Sustainability Analysis. IMF Working Paper, WP/08/58. http://dx.doi.org/10.5089/9781451869200.001

Eberhardt, M., \& Presbitero, A. (2013). This Time They Are Different: Heterogeneity and Nonlinearity in the Relationship Between Debt and Growth. IMF Working Papers, WP/13/248. http://dx.doi.org/10.5089/9781484309285.001

El-Mahdy, A., \& Torayeh, N. (2009). Debt Sustainability and Economic Growth in Egypt. International Journal of Applied Econometrics and Quantitative Studies, 6-1.

Escolano, J. (2010). A Practical Guide to Public Debt Dynamics, Fiscal Sustainability, and Cyclical Adjustment of Budgetary Aggregates. IMF, Technical Notes and Manuals.

Ghosh, A., Kim, J., Ostry, E., \& Qureshi, M. (2011). Fiscal Fatigue, Fiscal Space and Debt Sustainability in Advanced Economies. NBER Working Papers, W16782.

IMF. (2013). Staff Guidance Note for Public Debt Sustainability Analysis in Market- Access Countries. IMF.

IMF and the World Bank. (2012). Revisiting the Debt Sustainability Framework for Low-Income Countries. IMF and the World Bank.

IMF and the World Bank. (2009). Managing Public Debt: Formulating Strategies and Strengthening Institutional Capacity. IMF and the World Bank.

IMF and the World Bank. (2001). Guidelines for Public Debt Management. IMF and the World Bank.

Medeiros, J. (2012). Stochastic debt simulation using VAR models and a panel fiscal reaction function: results for a selected number of countries. European Commission, European Economy, Economic Papers, 459.

Ostry, J., Ghosh, A., Kim, J., \& Qureshi, M. (2010). Fiscal Space. IMF Staff Position Note, SPN/10/11.

Pescatori, A., Sandri, D., \& Simon, J. (2014). Debt and Growth: Is There a Magic Threshold? IMF Working Paper, WP/14/34.

Reinhart, C., \& Rogoff, K. (2013). Financial and Sovereign Debt Crises: Some Lessons Learned and Those Forgotten. IMF Working Paper, WP/13/266. http://dx.doi.org/10.5089/9781475552874.001

Rienhart, C., \& Rogoff, K. (2010). Growth in a Time of Debt. American Economic Review: Papers \& Proceedings, 100(2), 573-78. http://dx.doi.org/10.3386/w15639

Reinhart, C., Reinhart, V., \& Rogoff, K. (2012). Public Debt Overhangs: Advance-Economy Episodes since 1800. Journal of Economic Perspectives, 29(3), 69-86. http://dx.doi.org/10.1257/jep.26.3.69

Spoek, P. (2011). Testing the sustainability of the Croatian public debt with dynamic models. Privrednabanka Zagreb.

Stoian, A. (2011). A Simple Public Debt Dynamic Model for Assessing Fiscal Vulnerability: Empirical Evidence for EU Countries. Macrothink Institute, Research in Applied Economics, 3(2), E3. http://dx.doi.org/10.5296/rae.v3i2.1137

Tanner, E., \& Samake, I. (2006). Probabilistic Sustainability of Public Debt: A Vector Autoregression Approach for Brazil, Mexico, and Turkey. IMF Working Paper, WP/O6 


\section{Appendix I}

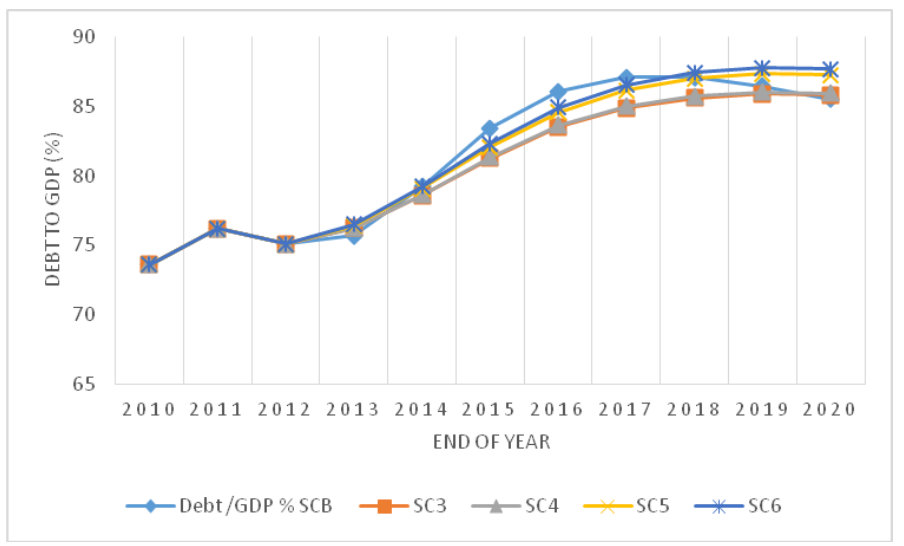

Figure 1. The forecasted value of public debt to GDP ratios for scenarios $(3,4,5$, and 6$)$

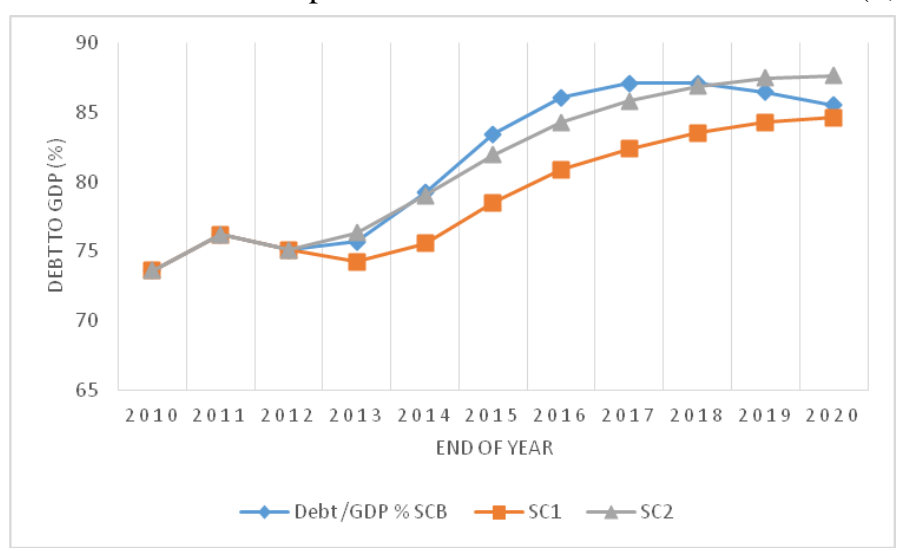

Figure 2. The forecasted value of public debt to GDP ratios for scenarios (1 and 2)

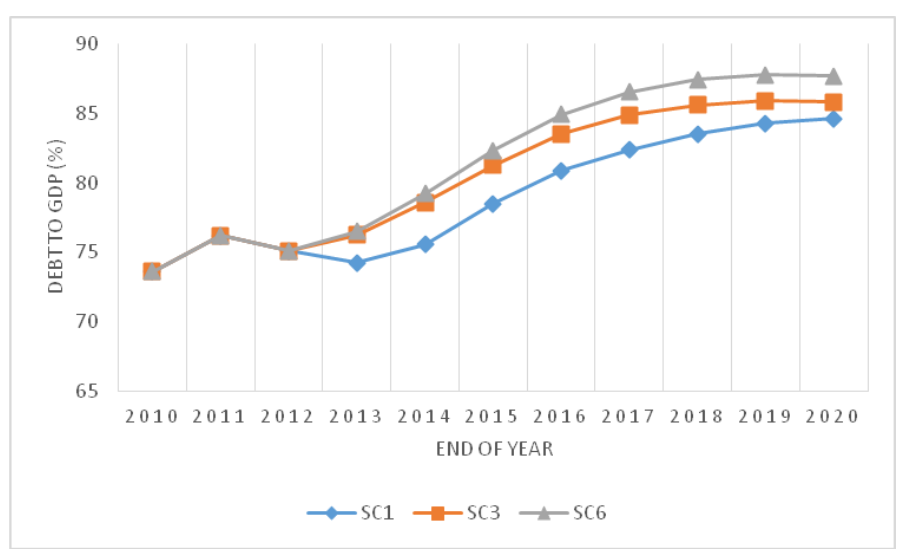

Figure 3. The forecasted value of public debt to GDP ratios for scenarios $(3,4$, and 6$)$ 


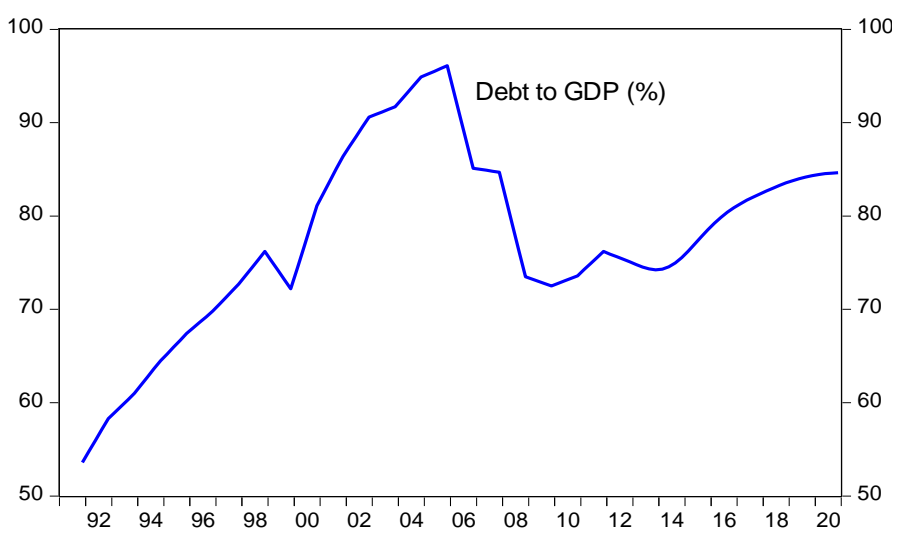

Figure 4. The forecasted value of public debt to GDP ratios for scenario (1)

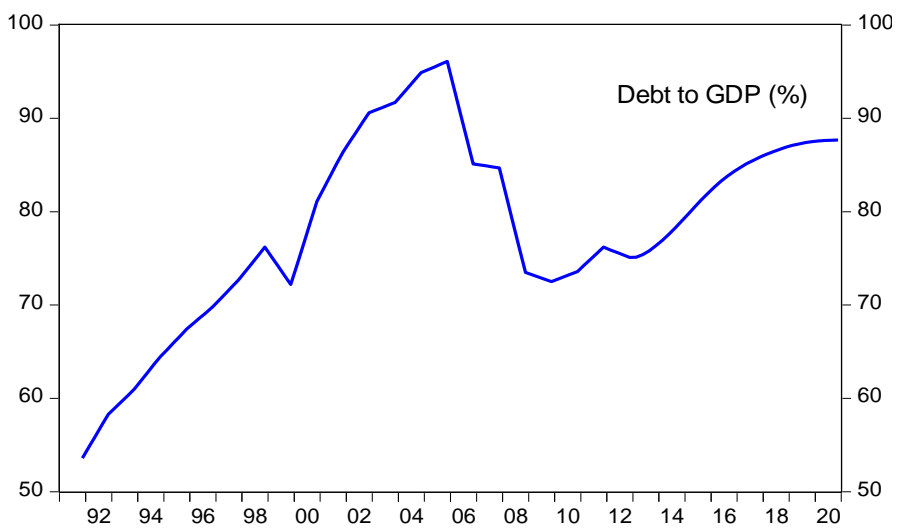

Figure 5. The forecasted value of public debt to GDP ratios for scenario (2)

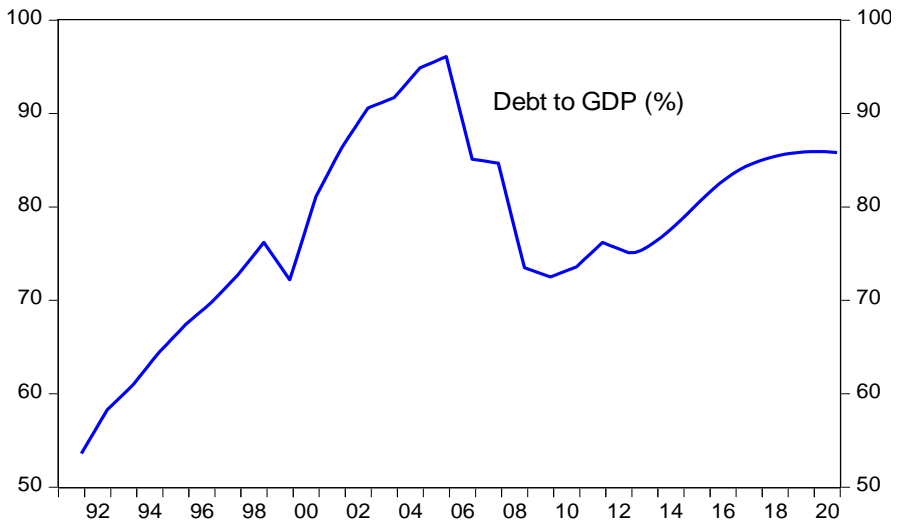

Figure 6. The forecasted value of public debt to GDP ratios for scenario (3) 


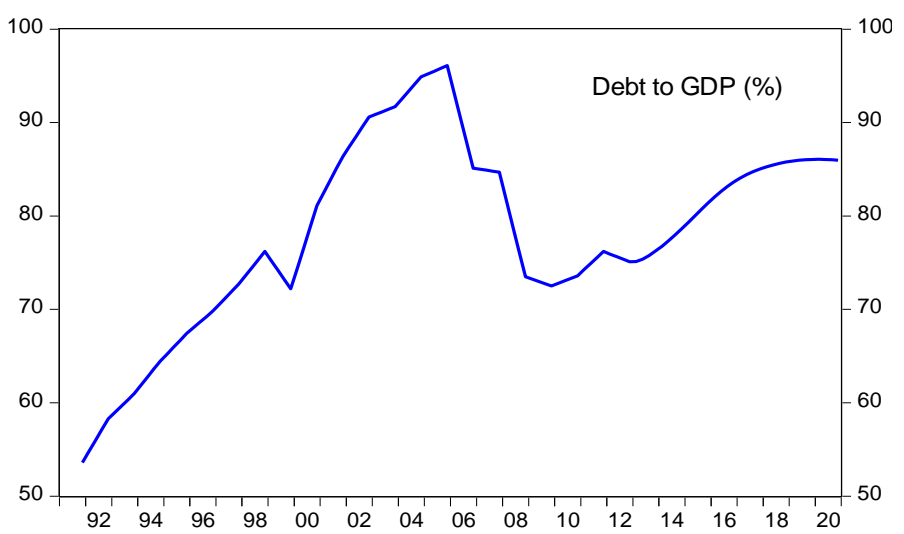

Figure 7. The forecasted value of public debt to GDP ratios for scenario (4)

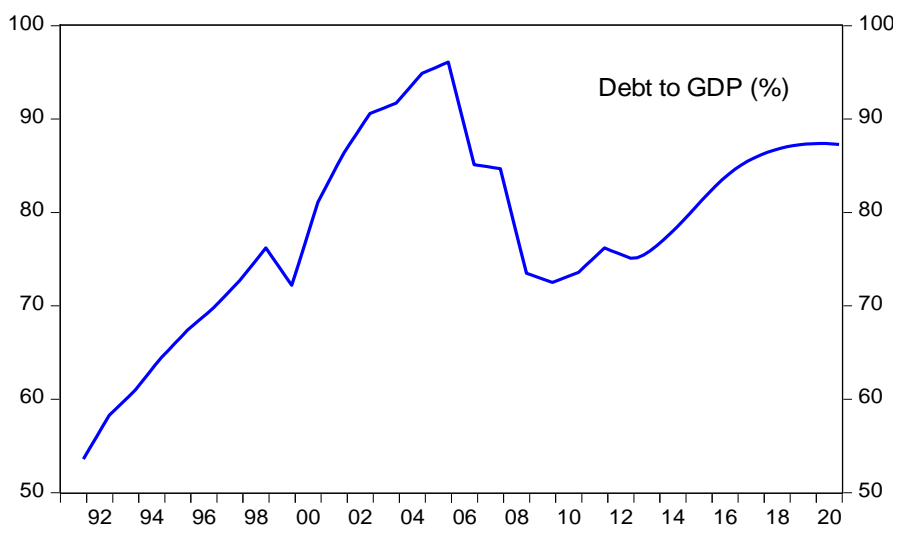

Figure 8 . The forecasted value of public debt to GDP ratios for scenario (5)

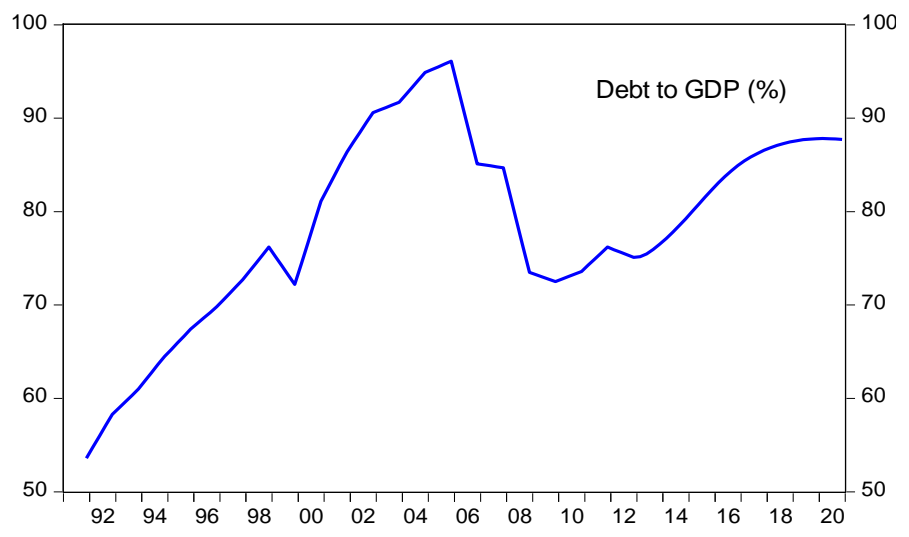

Figure 9. The forecasted value of public debt to GDP ratios for scenario (6)

\section{(c) EY}

This work is licensed under a Creative Commons Attribution 3.0 License. 